\title{
Teologia fundamental e ortopráxis
}

Orientadora: Profa. Maria Clara Lucchetti Bingemer

Pesquisador: Igor Januário da Silva

Fonte: $\mathrm{CNPq}$

\section{Introdução}

Nesta fase da pesquisa, iremos nos concentrar um pouco na reverberação da Teologia Fundamental na prática. Como sabemos, a TL se desloca da mera meditação e especulação sobre verdades para o viver essas verdades na prática, e sobretudo encontrar o seu sentido na prática e também, em certa medida, a partir da prática. Uma ética e um cristianismo devem se basear na empatia - o que atrai a sensibilidade e não simplesmente a razão. Isto parece ser a própria ética de Cristo. A ética do bom samaritano.

\section{Objetivos}

Estudar, a partir dos fundamentos da teologia fundamental de João Batista Libânio, as influências que ela traz para a práxis e para a ética. Repensar os códigos legais ou as convenções sociais pela ótica da empatia profunda. 